\title{
TINGKAT PENGETAHUAN LANSIA BERHUBUNGAN DENGAN RESILIENSI PADA LANSIA YANG DI TINGGAL MENINGGAL PASANGAN HIDUPNYA
}

\author{
Sri Puji Lestari*, Sonhaji, Rosario Alfonsina Baru \\ Sekolah Tinggi Ilmu Kesehatan Karya Husada Semarang \\ *lestari.budiyono@gmail.com
}

\begin{abstract}
ABSTRAK
Resiliensi merupakan ranah bimbingan pribadi secara sosial kepada individu agar dapat mendaptasi lingkungan sosialya, sehingga mampu mengatasi permasalahan sulit dalam hidupnya dan tetap terbebas dari simtom psikopatologi. Dalam tahap perkembangan usia lanjut sangat diperlukan adanya resiliensi dalam rangka menyesuaikan diri dan bertahan dalam keadaan yang malang dan/atau tidak menyenangkan dalam hidupnya, terlebih untuk para usia lanjut yang ditinggalkan oleh pasangan hidupnya. Tujuan penelitian ini untuk mengetahui hubungan Tingkat Pengetahuan Lansia dengan resiliensi pada lansia yang ditinggalkan karena kemeninggalan oleh pasangan hidupnya di Puskesmas Rowosari Kota Semarang . Metodelogi Penelitian : Jenis penelitian yang kuantitatif dengan rancangan Cross Sectional. Populasi dalam penelitian ini adalah lansia yang sudah ditinggalkan karena kemeninggalan oleh pasangan hidupya di wilayah kerja puskesmas Rowosari Kota Semarang sebanyak 30 responden.

Hasil penelitian menunjukkan bahwa Lansia yang ditinggalkan karena kemeninggalan oleh pasangan hidupnya di wilayah kerja Puskesmas Rowosari Kota Semarang yanag mempunyai pengetahuan baik, sebanyak 6 responden $(20,0 \%)$, pengetahuan cukup, sebanyak 13 responden $(43,3 \%)$ dan mempunyai resiliensi baik, sebanyak 16 responden $(53,3 \%)$ dan sebagian kecil mempunyai kejadian resiliensi kurang baik, sebanyak 14 responden $(46,7 \%)$. Ada hubungan antara pengetahuan dengan resiliensi pada lansia yang ditinggalkan karena kemeninggalan oleh pasangan hidupnya di wilayah kerja Puskesmas Rowosari Kota Semarang dengan $\mathrm{p}$ value fisher exact $0,000<0,05$
\end{abstract}

Kata kunci: pengetahuan, lansia, resiliensi

\section{KNOWLEDGE LEVEL OF ELDERLY RELATED TO THE RESELIENCE AMONG ELDERLY AFTER THE DEATH OF A SPOUSE}

\begin{abstract}
Resilience is the realm of personal social guidance to every individual who has difficultyor problems in his/her life and as well asto support he/she for free from psychopathology symptoms. In the stage of development of the elderly it is necessary to have resilience in order to adapt and survive in a situation that is unfortunate and / or unpleasant in life, especially for the elderly who have been left alone by their partner who had dead. The purpose of the study: To determine the relationship between the level or degree of knowledge of the elderly with the resilience of the elderly who have been left by their partner of spouses who dead in Rowosari Public Health Center, Semarang city, 2017. Type of research, I used quantitative research method by the Cross Sectional design. The population in this study is the elderly who have been left alone by his/her partner who dead in the work area of Rowosari Public Health Center, in Semarang City as many as 30 respondents. The result of the study, Elderly who have been left by his/her partner of spouses who dead in Rowosari Rowosari Public Health Center, Semarang city, has a good knowledge as much as 6 respondents (20.0\%), knowledge enough 13 respondents (43.3\%) and have good resilience as many as 16 respondents $(53,3 \%)$ and a small number had an incidence of poor resilience as many as 14 respondents (46.7\%). There is a relationship between knowledge with resilience in elderly who have been left by his/her partner of spouses who dead in Rowosari Public Health Center, Semarang city, with p value fisher exact 0,000 $<0,05$
\end{abstract}

Keywords: knowledge, resilienc, elderly 


\section{PENDAHULUAN}

Manusia adalah makhluk sosial yang memerlukan orang lain dalam mencapai tujuan hidup dan dapat menjalani kehidupannya, ketika manusia tersebut merasa memiliki orang-orang yang menyayanginya, maka seseorang tersebut akan merasa bahwa hidupnya berharga dan berguna. Manusia dalam rentang hidupnya, melewati tahap-tahap perkembangan dimana dalam tiap tahap kehidupannya memiliki berbagai tugas perkembangannya masing-masing (Carolina, 2008). Usia lanjut merupakan fase terakhir kehidupan seseorang yang merupakan cerminan bagaimana seseorang tersebut belajar dan mempersiapkan dirinya untuk menghadapi hari tuanya, sehingga proses belajar individu tersebut di masa-masa sebelumnya sangat berpengaruh terhadap kondisi usia lanjut tersebut di masa tua, hal ini berhubungan dengan psikologi perkembangan individu (Diah, 2016)

Data WHO pada tahun 2015 menunjukkan ada 901.000.000 orang berusia 60 tahun atau lebih yang terdiri dari $12 \%$ dari jumlah populasi. pada tahun 2050 populasi lansia di proyeksikan lebih dari 2 kali lipat di tahun 2015yaitu mencapai 2,1 milyar (Putri, 2015). Menurut data survei sosial ekonomi Nasional tahun 2015 Indonesia saat ini masuk dalam Negara berstruktur ageing population karena memiliki proporsi lanjut usia 60 tahun ke atas yang besar di atas 7\%, hal tersebut menunjukan bahwa lansia sebanyak 8,43\% dari seluruh penduduk Indonesia adalah lansia, dan berada pada urutan 108 dari seluruh Negara di dunia diprediksikan pula bahwa di tahun 2050, Indonesia akan masuk sepuluh besar Negara dengan jumlah lansia terbesar yaitu 10 juta lansia Menurut Data Kementrian RI Tahun 2015 di Indonesia lansia yang ditinggal meninggal oleh pasangannya adalah laki-laki $15,04 \%$ dan perempuan $56,045 \%$ dan Provinsi dengan jumlah lansia terbanyak adalah jawa Tengah $13,4 \%$ dan jumlah populasi lansia tersedikit adalah Papua 2,8\%. (Putri, 2015)

Data penduduk tersebut menunjukkan populasi lansia cenderung meningkat setiap tahunnya, sehingga akan dikuti pula meningkatnya masalah pada lansiayang berhubungan dengan penurunan fungsi fisik dan mental pada lansia dan saat mengalami masalah, kemampuan pada perawatan diri dalam menghadapi berbagai tekanan psikologi, baik lansia perempuan dan laki membutuhkan dukungan perhatian dalam penyesuian diri bagi lansia dalam perubahan peran baru di lingkungan dan kehidupan setelah di tinggal meninggal oleh pasangan hidupnya (Putri, 2015)

Penelitian yang dilakukan Wiwi Nur Asih mengatasi masalah tanpa pasangan hidup yang selama ini menemani, kemeninggalan orang yang dicintai membutuhkan proses penyesuaian diri untuk menerima dan bangkit kembali dari kesedihan maka diperlukan berbagai kemampuan untuk mengatasi dan beradaptasi bila terjadi masalah yang merugikan hidupnya. Dengan bertahan dalam keadaan tertekan sekali pun, atau bahkan berhadapan dengan kesengsaraan (adversity) maupun trauma yang dialami sepanjang kehidupannya (Asih, 2016)

Hasil penelitian yang dilakukan oleh Riska Hidayanti tahun 2015 di Dusun Gayaman Desa Gayaman Kecamatan Mojoanjar kabupaten Mojokerto sebagian besar responden menggunakan koping adaptif yaitu sebanyak (62,5\%). Hasil penelitian menunjukkan mayoritas responden menggunakan mekanisme koping pada lansia yang di tinggal meninggal pasangan hidupnya (Hidayanti, 2015) Permasalahan lainnya yang seringkali dialami para usia lanjut adalah Kehilangan berpisah dengan sesuatu yang sebelumnya ada atau dimiliki, baik sebagian atau keseluruhan (Riyadi dan Purwanto,) Menangis, memanggil nama orang yang sudah meninggal secara terus-menerus, marah, sedih dan kecewa merupakan beberapa respon yang tampak saat seseorang mengalami peristiwa kehilangan, terutama akibat kemeninggalan orang yang dicintai. Keadaan seperti inilah yang menurut Puri, Laking, dan Treasaden disebut sebagai proses berduka, yang merupakan suatu proses psikologis dan emosional yang dapat diekspresikan secara internal maupun eksternal setelah kehilangan (Carolina, 2008)

Peningkatan kemampuan yang dimiliki lansia mengacu pada kemandirian diri dalam aktifitas 
sehari-hari Penelitian yang dilakukan oleh Mandasari Puspita Susan yang dihadapi oleh para lansia setelah ditinggal meninggal pasangan hidup, perubahan ini menimbulkan efek penyesuaian diri dalam pola kehidupankarena adanya kegiatan yang ikuti, dengan berbagi pikiran dalam keluarga, berhubungan sosial dengan lingkungan dan mengikuti kegiatan keagaman (Susan, 2015)

Studi pendahuluan yang dilakukan oleh peneliti pada 15 juli 2017 di wilayah kerja puskesmas Rowosari tercatat bahwa jumlah lansia yang diperoleh dari data posyandu lansia sebanyak 60 orang dengan kriteria lansia yang sudah ditinggal meninggal pasangan hidupnya sebanyak terh 30 orang dengan jenis kelamin perempuan sebanyak 17 orang dan lansia lakilaki 13orang. Hasil wawancara yang dilakukan pada 10 orang lansia 5 orang lansia perempuan berusia 60-80 tahun, mengatakan bahwa mereka sudah ditinggal meninggal pasangannya dengan lama waktu 3 bulan, dan 2 lainnya dengan lama waktu 2 tahun. 5 lansia laki-laki 3 orang dengan lama waktu ditinggal pasangan hidupnya 1 tahun dan 6 bulan. 2 orang lainnya 2 tahun. Mereka juga mengatakan rasa kerinduan yang mendalam kepada pasangannya, untuk berkumpul bersama, mereka juga mengatakan kesepian dan tidak percaya jika pasangan mereka sudah tidak ada. Dampak negative yang dialami lansia ketika ditinggal meninggal pasangan hidup adalah perasaan sedih yang berkepanjangan akan terjadi perubahan pola makan dan tidur merasa pesimis dan tak berdaya.
Lansia yang ditinggal meninggal pasangannya bisa bertahan hidup dengan mencari nafkah sendiri dalam memenuhi kebutuhan hidup, walau ada yang masih tinggal dengan keluarga, hidup menyendiri dan menutup diri terhadap lingkungan. maka diperlukan kemampuan diri dalam mencapai kehidupan lansia yang sejahtera dengan mengatasi masalah dengan beradaptasi, atau bangkit kembali dan individu dapat memandang permasalahan tersebut sebagai hal yang wajar bagi kehidupan manusia dan merupakan kondisi normal yang terjadi sepanjang kehidupan manusia. Penelitian ini bertujuan untuk untuk mengetahui hubungan Tingkat Pengetahuan Lansia dengan resiliensi pada lansia yang ditinggalkan karena kemeninggalan oleh pasangan hidupnya melalui penelitian kuantitatif.

\section{METODE}

Jenis penelitian yang digunakan adalah penelitian kuantitatif dengan rancangan desain penelitian ini adalah Cross Sectional yang mencari hubungan antara variabel bebas Tingkat Pengetahuan dengan variabel terikat (Reseliensi). Populasi dalam penelitian ini adalah lansia yang sudah ditinggal meninggal oleh pasangan hidupya di wilayah kerja puskesmas Rowosari Kota Semarang sebanyak 30 responden dalam penelitian ini mengunakan Teknik Purposive Sampling. Data dianalisis menggunakan uji Chi square.

\section{HASIL}

\section{Analisa Univariat}

\section{a. Pengetahuan}

Pengetahuan lansia yang ditinggal meninggal pasangan hidupnya disajikan pada tabel 1 .

Tabel 1.

Pengetahuan lansia yang ditinggal meninggal pasangan hidupnya $(\mathrm{n}=30)$

\begin{tabular}{lcc}
\hline \multicolumn{1}{c}{ Pengetahuan } & $\mathrm{f}$ & $\%$ \\
\hline Baik & 6 & 20.0 \\
Cukup & 13 & 43.3 \\
Kurang & 11 & 36.7 \\
\hline
\end{tabular}

Berdasarkan tabel 1, maka dapat diketahui bahwa lansia yang ditinggal meninggal pasangan hidupnya di wilayah kerja Puskesmas Rowosari Kota Semarang mayoritas mempunyai pengetahuan cukup sebanyak 13 responden. b. Resiliensi

Resiliensi pada lansia yang ditinggal meninggal pasangan hidupnyasajikan pada tabel 2. 
Tabel 2.

Resiliensi pada lansia yang ditinggal meninggal pasangan hidupnya

\begin{tabular}{lcc}
\hline \multicolumn{1}{c}{ Resiliensi } & f & $\%$ \\
\hline Baik & 16 & 53.3 \\
Kurang baik & 14 & 46.7 \\
\hline Berdaskan
\end{tabular}

Berdasarkan tabel 2, maka dapat diketahui bahwa lansia yang ditinggal meninggal pasangan hidupnya di wilayah kerja Puskesmas Rowosari Kota Semarang sebagian besar mempunyai resiliensi baik.

Analisa bivariat
Analisis bivariat terkait hubungan
pengetahuan dengan resiliensi pada lansia yang
ditinggal meninggal pasangan hidupnya
disajikan pada tabel 3.

Tabel 3.

Tabel silang antara pengetahuan dengan resiliensi pada lansia yang ditinggal meninggal pasangan hidupnya $(\mathrm{n}=30)$

\begin{tabular}{|c|c|c|c|c|c|c|c|}
\hline \multirow{3}{*}{ Pengetahuan } & \multicolumn{4}{|c|}{ Resiliensi } & \multirow{2}{*}{\multicolumn{2}{|c|}{ Jumlah }} & \multirow{3}{*}{ p-value } \\
\hline & \multicolumn{2}{|c|}{ Baik } & \multicolumn{2}{|c|}{ kurang baik } & & & \\
\hline & $\mathrm{f}$ & $\%$ & f & $\%$ & $f$ & $\%$ & \\
\hline Baik & 6 & 20,0 & 0 & 0,0 & 6 & 20,0 & 0,000 \\
\hline Cukup & 9 & 30,0 & 4 & 13,3 & 13 & 43,3 & \\
\hline Kurang & 1 & 3,3 & 10 & 33,3 & 11 & 36,7 & \\
\hline
\end{tabular}

Berdasarkan tabel 3, maka dapat diketahui mengingat dan memiliki pemahaman berupa bahwa lansia yang ditinggal meninggal pasangan hidupnya di wilayah kerja Puskesmas Rowosari Kota Semarang yang mempunyai pengetahuan baik sebagian besar mempunyai resiliensi baik sebanyak 6 responden $(20,0 \%)$, yang mempunyai pengetahuan cukup sebagian besar mempunyai resiliensi baik sebanyak 9 responden $(30,0 \%)$ dan yang mempunyai pengetahuan kurang sebagian besar mempunyai resiliensi kurang baik sebanyak 10 responden $(33,3 \%)$.

\section{PEMBAHASAN}

\section{Pengetahuan}

Lansia yang ditinggal meninggal pasangan hidupnya mempunyai pengetahuan baik sebanyak 6 responden $(20,0 \%)$, pengetahuan cukup sebanyak 13 responden $(43,3 \%)$ dan yang mempunyai pengetahuan kurang sebanyak 11 responden $(36,7 \%)$. Pada umumnya setelah orang memasuki lansia, ia mengalami penurunan fungsi kognitif meliputi proses belajar, persepsi, pemahaman, pengertian dan lain-lain sehingga menyebabkan reaksi dan perilaku lansia menjadi makin lambat Pengetahuan merupakan domain yang sangat penting untuk terbentukmya perilaku seseorang. Tingkat pengetahuan yang diukur dalam penelitian kali ini adalah pengetahuan lansia tentang Reseliensi. Domain kognitif yang dilihat dari responden adalah tahu, artinya dapat mengingat dan memiliki pemahaman berupa
informasi dalam pengalaman hidup media tentang reseliensi atau kemampuan diri dalam mengatasi masalah (Notoadmodjo 2003).

\section{Resiliensi}

Lansia yang ditinggal meninggal pasangan hidupnya di wilayah kerja Puskesmas Rowosari Kota Semarang sebagian besar mempunyai resiliensi baik sebanyak 16 responden $(53,3 \%)$ dan sebagian kecil mempunyai kejadian resiliensi kurang baik sebanyak 14 responden (46,7\%). Glanstz dan Johhson yang menyatakan bahwa resiliensi adalah istilah ketahanan dalam ilmu psikologi positif. Kata resiliensi mengacu pada kemampuan atau kapasitas individu untuk bertahan dan bangkit kembali dari suatu keadaan yang menekanguna memulihkan kebahagiaan setelah menghadapi situasiyang tidak menyenangkan. Resiliensi adalah kemampuan atau kapasitas yang dimiliki individu untuk mengatasi dan melakukan adaptasi terhadap kejadian yang berat atau masalah yang terjadi dalam kehidupan seseorang. Kemampuan tersebut meliputi kemampuan bertahan dalam keadaan tertekan, dan bahkan berhadapan dengan kesengsaraan atau trauma yang dialami dalam kehidupan (Glantz and Johnson, 2002). 
Maneerat mengemukakan bahwa individu yang resiliensi memiliki tiga domain yang mempengaruhi terbentuknya perilaku resiliensi meliputi: kekuatan diri (I Am), memiliki dukungan eksternal (I Have), dan memiliki kemampuan interpersonal $(I$ Can). Werner yang menekankan pada proses terbentuknya resiliensi dalam perkembangan individu, yaitu: Pertama, berasal darikondisi personal atau internal (kemampuan individu untuk berkomunikasi, mudah bergaul, dan memiliki kemampuan menyelesaikan masalah). Kedua, berasaldari lingkungan keluarga dan orang terdekat yang perduli (eksternal). Ketiga, lingkungan komunitas (interpersonal) (Maneraat and Boonyasopun, 2011).

Hasil penelitian sebagian besar responden mempunyai pengetahuan baik, hal tersebut responden telah mengetahui dalam mengatasi dan beradaptasi bila terjadi sesuatu yang merugikan hidupnya. Sedangkan pengetahuan cukup responden sudah mendapat informasi dari keluarga atau tenaga kesehatan cara mengatasi bila terjadi keadaan yang sulit terjadi, dan yang mempunyai pengetahuan kurang hal tersebut responden belum tau sama sekali cara mengatasi apabila terjadi situasi yang tidak diinginkan dan merugikan responden.

\section{Hubungan pengetahuan dengan resiliensi pada lansia yang ditinggal meninggal pasangan hidupnya}

Lansia yang ditinggal meninggal pasangan hidupnya di wilayah kerja Puskesmas Rowosari Kota Semarang yang mempunyai pengetahuan baik sebagian besar mempunyai resiliensi baik sebanyak 6 responden $(20,0 \%)$, yang mempunyai pengetahuan cukup sebagian besar mempunyai resiliensi baik sebanyak 9 responden $(30,0 \%)$ dan yang mempunyai pengetahuan kurang sebagian besar mempunyai resiliensi kurang baik sebanyak 10 responden (33,3\%). Dari hasil olah data didapatkan nilai $\mathrm{X}^{2}$ continuity correction sebesar 10.997 dengan $\mathrm{p}$ value fisher exact $0,000<0,05$ maka dapat disimpulkan ada hubungan antara pengetahuan dengan resiliensi pada lansia yang ditinggal meninggal pasangan hidupnya di wilayah kerja Puskesmas Rowosari Kota Semarang
Resiliensi didefinisikan sebagai kemampuan atau kapasitas yang dimiliki individu untuk mengatasi dan melakukan adaptasi terhadap kejadian yang berat atau masalah yang terjadi dalam kehidupan seseorang. Kemampuan tersebut meliputi kemampuan bertahan dalam keadaan tertekan, dan bahkan berhadapan dengan kesengsaraanatau traumayang dialamidalam kehidupan. Middleton menyatakan bahwa individu yang mengalami stres atau tekanan akibat kehilangan seseorang yang dekat dalam hidup mereka beranggapan akan mengalami kesulitan hidup di masa depan. (Reivich and Shatte, 2002).

Penelitian yang dilakukan Luthans, menyatakanbahwa resiliensi menjadi faktor yang sangat penting untuk dapat mengubah ancaman-ancaman yang ada di sekitar menjadi kesempatan untuk bertumbuh, berkembang, dan meningkatkan kemampuan untuk beradaptasi demi perubahan kearah yang baik. Penelitian lain juga dilakukan oleh Moneerat, yang meneliti tentang struktur konsep resiliensi pada lansia Thailand yang mengambil sampel dari empat provinsi di Thailand terhadap 14 lansia berusia antara 6282tahun yang mengalami tantangan keras dalam hidup seperti kehilangan rumah dan memiliki penyakit kronis. (Maneerat and Boonyasopun, 2011). Hasil penelitian menunjukkan bahwa resiliensi adalah bentuk adaptasi sukses dalam menghadapi kesulitan besar dalam kehidupan seperti kemiskinan, penyakit, trauma masa lalu, dan kehilangan orang terdekat. Lebih lanjut dijelaskan bahwa resiliensi disebut sebagai kualitas pribadi yang memungkinkan lansia untuk berkembang dan bertahan di tengah- tengah kesulitan. (Norman, E 2000)

\section{SIMPULAN}

Lansia yang ditinggal meninggal pasangan hidupnya di wilayah kerja Puskesmas Rowosari Kota Semarang yanag mempunyai pengetahuan baik sebanyak 6 responden $(20,0 \%)$, pengetahuan cukup sebanyak 13 responden $(43,3 \%)$ dan yang mempunyai pengetahuan kurang sebanyak 11 responden $(36,7 \%)$. Lansia yang ditinggal meninggal pasangan hidupnya di wilayah kerja Puskesmas Rowosari Kota Semarang sebagian besar mempunyai resiliensi baik sebanyak 16 responden $(53,3 \%)$ dan sebagian kecil 
mempunyai kejadian resiliensi kurang baik sebanyak 14 responden $(46,7 \%)$. Ada hubungan antara pengetahuan dengan resiliensi pada lansia yang ditinggal meninggal pasangan hidupnya di wilayah kerja Puskesmas Rowosari Kota Semarang dengan $\mathrm{p}$ value fisher exact $0,000<0,05$.

\section{DAFTAR PUSTAKA}

Ekowati Retno Carolina. 2008.Penyesuaian Diri Terhadap Hilangnya Pasangan Hidup Pada Lansia.

Glantz, M and Johnson, J. 2002. Resilience and development positive life adaptation. USA : Kluwer Academic,

Hidayanti Riska. 2015.Mekanisme Koping Pada Lansia Yang ditinggal Meninggal Pasangan Hidupnya Di Dusun Gayaman Kec Mojoanyar Kabupaten Mojokerto.

Putri, I Gusti Jayanti, 2015. Demografi Populasi lanjut usia Dunia Dan Indonesia. United Nation. [Online] [Cited: Juli senin, 2017.] Http://WWW.slideShereNotPre,

Mandasari Puspita Susan. 2015.Perbedaan Loneliness Pada Pria Dan Wanita Usia Lanjut Setelah Mengalami kemeninggalan Pasangan Hidup

Maneerat . S, Isaramalai . S, \& Boonyasopun .U. (2011). A Conceptual Structure of Resilience among Thai Elderly. International Journal of Behavioral Science Vol. 6, No. 1, 25 - 40

Notoadmodjo. (2003). Pendidikan dan perilaku Kesehatan . Jakarta: PT Rineka Cipta. www repository.umy.ac.id. Diakses pada 2016

Norman, E;. 2000. Resiliency enhancement: Putting the strength perspective into social work parctice. New York: Colombia University Press,

Reivich, K and Shatte, A. 2000. The resilience factor: 7 skilss for overcoming life's inevitable obstacles. New York: Random House Inc
Widowati Erlita Diah. 2016.Tingkat Resilensi usia Lanjut Dipanti Sosial Tresna Wrdha Abiyoso Sleman.. Yogyakarta: s.n.,

Wiwi Nur Asih, D. U. 2016. Strategi Koping pada Lansia yang ditinggal meninggal Pasangan Hidupnya. 